\title{
Zadośćuczynienie pieniężne za krzywdę osoby najbliższej bezpośrednio poszkodowanego a odpowiedzialność zakładów ubezpieczeń - przegląd orzecznictwa
}

Problem przyznawania zadośćuczynień za krzywdę osoby najbliższej bezpośrednio poszkodowanego jest wyzwaniem nie tylko dla zakładów ubezpieczeń, ale również dla sqdów powszechnych. Artykuł stanowi próbę opracowania niejednolitego orzecznictwa w przedmiotowych sprawach i podsumowania jego konsekwencji dla rynku ubezpieczeniowego.

W części pierwszej zostało opisane orzecznictwo sqdów powszechnych zasqdzajace zadośćuczynienie pieniężne na rzecz osób najbliższych z uwzględnieniem rozszerzającej wykładni przepisów prawa cywilnego. W części dalszej przedstawiono wyroki sq̨dów powszechnych oddalające powództwa i odwołujace się do tradycyjnego rozumienia przepisów o ochronie dóbr osobistych. Następnie omówiono uchwały Saqu Najwyższego, stanowiq̨ce próbę ujednolicenia wykładni przepisów w przedmiotowych sprawach, oraz podkreślono ich znaczenie dla rynku ubezpieczeniowego. We wnioskach wskazano na konieczność ustalenia stabilnych i spójnych reguł przyznawania rekompensaty za krzywdę osób najbliższych w zakładach ubezpieczeń oraz zaakcentowano istotność uchwał Sadu Najwyższego dla stworzenia jednolitej polityki w powyższym zakresie. W podsumowaniu podkreślono również konieczność stworzenia jasnych i niebudzq̨cych watpliwości przepisów, które byłyby podstawq do zasqadzania należnych pokrzywdzonym rodzinom roszczeń.

Słowa kluczowe: zadośćuczynienie, osoby najbliższe, bezpośrednio pokrzywdzony, rynek ubezpieczeniowy, ochrona dóbr osobistych, dobra osobiste. 


\section{Wstęp}

Pozostawanie osoby najbliższej w ciężkim stanie zdrowia, który uniemożliwia jej samodzielne funkcjonowanie, nie tylko stanowi trwałą krzywdę dla osób najbliższych bezpośrednio poszkodowanego, ale również prowadzi do szeregu konsekwencji w sferze praw poszkodowanego i jego rodziny. Zmagania z tạ bez watpienia trudną tematyką można zauważyć szczególnie wyraźnie w obszarze rynku ubezpieczeniowego, stojącego przed problemem wypłaty zadośćuczynień za krzywdę osób najbliższych wobec bezpośrednio poszkodowanego. Problematyka ta budzi kontrowersje w przedmiocie wyboru podstawy prawnej, na mocy której takie świadczenie jest zasądzane, a także zmaga się z niejednolitością orzecznictwa, a w konsekwencji - z licznymi wypowiedziami doktryny ${ }^{1}$. Niniejszy artykuł stanowi próbę opracowania nowej praktyki orzeczniczej w obszarze zadośćuczynienia zasądzanego osobom najbliższym bezpośrednio poszkodowanego oraz wyzwań stawianych rynkowi ubezpieczeń na tle najnowszych uchwał Sądu Najwyższego związanych z przedmiotowym tematem.

W części pierwszej zostanie przytoczona analiza najnowszego orzecznictwa wybranych sadów powszechnych - w pierwszej kolejności wyroki zasądzające zadośćuczynienie, a następnie przypadki, w których powództwa zostały oddalone. Dalsza część koncentruje się na opracowaniu najnowszego orzecznictwa Sądu Najwyższego w omawianym temacie. We wnioskach autorki przedstawiają wskazówki i możliwe rozwiązania istotne z punktu widzenia praktyki zakładów ubezpieczeń.

\section{Orzecznictwo sądów powszechnych zasądzające zadośćuczynienie pieniężne na rzecz osób najbliższych wobec bezpośrednio poszkodowanego}

Jak zostało wspomniane powyżej, w prawie polskim brak obecnie dosłownego i bezpośredniego przepisu, który przyznawałby pokrzywdzonym członkom rodziny wypłatę zadośćuczynienia za cierpienia psychiczne wynikające z przebywania osoby bliskiej w ciężkim stanie zdrowia, a niemożliwe jest zastosowanie $w$ drodze analogii art. 446 § 4 k.c., gdyż nie ma tutaj mowy o śmierci poszkodowanego. Przepisem wykorzystywanym przez sady jest w takiej - bez watpienia trudnej - sytuacji art. 448 k.c. w zw. z art. 24 § 1 k.c. W ostatnim czasie pojawiło się kilka istotnych z punktu widzenia omawianej problematyki orzeczeń sądów powszechnych.

Pierwszym orzeczeniem, które zasługuje tutaj na omówienie, jest wyrok Sądu Okręgowego w Ostrołęce ${ }^{2}$. Stan faktyczny jest następujący: syn powódki doznał ciężkich obrażeń ciała w wyniku

1. Na temat ustalania wysokości zadośćuczynienia za krzywdę osób pozostających w stanie wegetatywnym wypowiedziała się m.in. Beata Janiszewska, stwierdzając słusznie, że kwestia doznania krzywdy przez poszkodowanych przebywających w stanie wegetatywnym w zasadzie nie budzi wạtpliwości. Por. B. Janiszewska, 0 ustalaniu wysokości zadośćuczynienia za krzywdę, „Monitor Prawniczy” 2015, nr 23, s. 1270. Podobnie również Kinga Michałowska wskazując, że sam fakt ochrony nie jest w tym obszarze sprawą kontrowersyjną, a krytyką obarczona powinna zostać przede wszystkim niewłaściwa kwalifikacja dobra osobistego. K. Michałowska, Niemajatkowe wartości życia rodzinnego w polskim prawie cywilnym, www.sip.legalis.pl [dostęp: 1.10.2018].

2. Wyrok Sądu Okręgowego w Ostrołęce z dnia 31 sierpnia 2017 r., sygn. akt I C 596/17, niepubl. 
wypadku samochodowego, na skutek czego popadł w stan śpiączki i doznał kurczowego porażenia czterokończynowego, a w konsekwencji stał się niezdolny do samodzielnej egzystencji. Lekarze ocenili stan bezpośrednio poszkodowanego jako bardzo ciężki, a szanse na jego wybudzenie zerowe. Po stronie pozwanej stanałł zakład ubezpieczeń, w którym sprawca wypadku był ubezpieczony z tytułu odpowiedzialności cywilnej posiadaczy pojazdów mechanicznych. W omawianej sprawie zasądzone zostało 150 tys. zł tytułem zadośćuczynienia za doznaną krzywdę na podstawie art. 448 k.c. w zw. z art. 24 § 1 k.c., a jako dobro chronione oznaczone zostało prawo do życia w rodzinie, prawo do niezakłóconego życia rodzinnego i prawo do utrzymania więzi z najbliższym członkiem rodziny.

Sąd wskazał, że z uwagi na otwarty katalog dóbr osobistych stanowiących przedmiot ochrony na podstawie wskazanego przepisu należy wskazać, że nie ma powodu, by nie traktować prawa do życia w rodzinie i utrzymania tego rodzaju więzi - jak też prawa do niezakłóconego życia rodzinnego oraz rodzicielstwa, a także prawa do wychowywania biologicznych dzieci - jako wartości chronionej na podstawie wskazanego przepisu. Zaznaczył również, że powódka ze względu na stan syna nie jest w stanie realizować z nim więzi w takim kształcie, w jakim były one realizowane dotychczas. Podkreślił, że w przypadku stanu wegetatywnego (tj. niezdolności do samodzielnego komunikowania się, braku reakcji na bodźce, a tym samym braku zdolności do samodzielnego funkcjonowania] nie istnieja podstawy do dyferencjacji pomiędzy zerwaniem więzi rodzinnej wskutek śmierci a niemożnością nawiązania tej więzi z uwagi na poważny uszczerbek na zdrowiu. Tym samym odrzucił twierdzenie pozwanego zakładu ubezpieczeń, zgodnie z którym więź rodzinna w przypadku pozostawania osoby bliskiej w stanie wegetatywnym jest jedynie osłabiona, a nie zerwana całkowicie. Zaznaczył również, że krzywda powódki ma charakter samoistny. Wśród okoliczności uzasadniających zasądzenie roszczenia pominięte zostały z kolei skutki niejako logistyczne, powiązane ze zmianą sytuacji życiowej powódki (konieczność opieki nad synem, rezygnacja z pracy męża powódki]. Przy ocenie stanu faktycznego i prawnego sąd skupił się wyłącznie na krzywdzie emocjonalnej powódki wynikającej z utraty kontaktu z dzieckiem.

W przedmiocie odpowiedzialności zakładu ubezpieczeń podkreślone zostało, że odpowiedzialność ubezpieczyciela sięga tak daleko, jak odpowiedzialność cywilna ubezpieczonego. Sạd uznał ponadto, że ubezpieczyciel odpowiada zgodnie z zasada pełnej kompensacji szkody, w granicach wyznaczonych adekwatnym związkiem przyczynowym (rozumianym jako obejmujący nie tylko bezpośrednie następstwa zdarzeń, ale również znacznie szerszy kontekst).

Kolejnym, podobnym w zakresie rozumowania orzeczeniem, jest wyrok Sądu Okręgowego w Warszawie ${ }^{3}$. Strona powodową był dwunastoletni chłopiec, którego matka była ofiarą wypadku samochodowego i doznała w jego wyniku na tyle poważnego uszczerbku na zdrowiu, że od chwili zdarzenia (tj. od ok. siedmiu lat) znajdowała się w utrwalonym stanie wegetatywnym. Kierujący samochodem został uznany winnym spowodowania wypadku i w sprawie karnej został warunkowo skazany na karę pozbawienia wolności. Pozwanym był zakład ubezpieczeń, z którym sprawca wypadku zawarł umowę ubezpieczenia OC. Na rzecz powoda zasądzona została kwota 1000 tys. zł tytułem zadośćuczynienia za doznaną krzywdę na mocy, analogicznie jak w poprzedniej sprawie, art. 448 k.c. w zw. z art. 24 § 1 k.c. Należy tutaj również zaznaczyć, że obecnie, równolegle w stosunku do przedmiotowej sprawy, toczy się sprawa o zadośćuczynienie z powództwa pokrzywdzonej wypadkiem matki.

3. Wyrok Sądu Okręgowego w Warszawie z dnia 31 stycznia 2018 r., sygn. akt IV C 637/16, niepubl. 
W opisywanej sprawie sąd uznał, że odpowiedzialność zakładu ubezpieczeń w stosunku do osoby trzeciej (innej osoby, która nie uczestniczyła bezpośrednio w wypadku) jest niekwestionowalna. Orzekł również, że na skutek wypadku doszło do naruszenia dobra osobistego w postaci prawa do więzi rodzinnej z najbliższym członkiem rodziny. Wskazał, że więź między powodem a jego matką została przerwana nagle, w związku z czym matka nie może brać udziału w wychowaniu i życiu syna. Nie pozostaje to bez skutku na jego funkcjonowanie psychiczne i społeczne - powód zdiagnozowany został z zespołem stresu pourazowego oraz z umiarkowaną niepełnosprawnością, ma problemy w szkole, nie radzi sobie w kontaktach z rówieśnikami, nie potrafi wyrażać własnych uczuć oraz unika rozmów dotyczących matki. Tak samo, jak w poprzednio opisywanej sprawie, sąd orzekł, że mimo tego, że osoba najbliższa żyje, to pozostawanie w stanie wegetatywnym uniemożliwia jej funkcjonowanie zarówno w społeczeństwie, jak i w rodzinie, a tym samym nie pozwala na pełnienie funkcji rodzicielskich w stosunku do powoda. Ważny również wydaje się fakt, że sąd zdecydował się na wymienienie kryteriów, które pełnią funkcję pomocniczą wobec oceny rozmiarów krzywdy. Są to, zdaniem sądu, dramatyzm doznań osoby bliskiej, poczucie osamotnienia i pustki, cierpienia moralne, wstrząs psychiczny wywołany śmiercią osoby bliskiej, rodzaj i intensywność więzi łączącej pokrzywdzonego ze zmarłym (w tym przypadku z osobą znajdująca się w stanie wegetatywnym ), wystapienie zaburzeń będących skutkiem śmierci, na przykład depresji czy nerwicy, stopień, w jakim pokrzywdzony będzie umiał się znaleźć w nowej rzeczywistości, zdolność zaakceptowania tej nowej rzeczywistości, a także wiek pokrzywdzonego. Sąd wskazał również, że zadośćuczynienie w przedmiotowej sprawie nie pełni funkcji typowo kompensacyjnej, bowiem nie jest możliwe miarkowanie takiego uszczerbku, natomiast ma przede wszystkim umożliwić osobie poszkodowanej powrót do normalnego życia.

Zadośćuczynienia za krzywdę spowodowaną przebywaniem osoby bliskiej w stanie wegetatywnym z powodu poszkodowania w wypadku komunikacyjnym dotyczy również wyrok Sąu Okręgowego w Gliwicach ${ }^{4}$. Sprawa toczyła się z powództwa matki oraz dwójki małoletnich dzieci poszkodowanego przeciwko zakładowi ubezpieczeń ponoszącemu odpowiedzialność cywilna za skutki ww. zdarzenia. Bezpośrednio poszkodowany doznał na tyle dotkliwego urazu mózgu, że od chwili wypadku przebywał w stanie wegetatywnym - bez zdolności samodzielnego oddychania, przełykania oraz bez możliwości nawiązania jakiegokolwiek świadomego kontaktu, na skutek czego został również całkowicie ubezwłasnowolniony.

Analogicznie jak w poprzednich sprawach sąd dokonał wykładni pojęcia dóbr osobistych w taki sposób, że zaliczył do ich katalogu więzi rodzinne utrzymywane za życia osoby, której dotyczą. Wskazał co prawda kontrowersje wynikające z utrwalonego orzecznictwa (jak kwestionowanie więzi rodzinnych jako dobra stricte osobistego ze względu na brak takiego bezpośredniego charakteru), uznał natomiast, że ma to zastosowanie jedynie w sytuacji, w której więź tego rodzaju faktycznie została zerwana, a nie tylko osłabiona (na skutek np. pogorszenia stanu zdrowia poszkodowanego]. Tego rodzaju sytuację, tj. polegającą na trwałym osłabieniu więzi rodzinnych, należałoby bowiem, zdaniem sądu, kwalifikować jako krzywdę naturalną, skutkującą oczywiście w wielu sytuacjach w sposób dramatyczny dla dotkniętych nim podmiotów, ale jako pozostająca poza obszarem kompensacji z art. 448 k.c.

Niemniej jednak sąd uznał, że w przedmiotowej sprawie można mówić o faktycznym zerwaniu więzi rodzinnych w sposób porównywalny, jak gdyby doszło do śmierci poszkodowanego.

4. Wyrok Sądu Okręgowego w Gliwicach z dnia 31 października 2017 r., sygn. akt XII C 65/17, niepubl. 
W kwestii miarkowania zadośćuczynienia sąd wskazał również, że wyższa kwota przysługuje matce dzieci - jako szczególnie obciążonej ze względu na konieczność opieki nad pozostającym w stanie wegetatywnym mężem - niż dzieciom, którym - ze względu na małoletniość - łatwiej jest zaadaptować się do zmienionych okoliczności.

Nieco inny stan faktyczny, choć podobny charakter rozstrzygnięcia, prezentuje wyrok Sądu Okręgowego w Warszawie ${ }^{5}$. W wyniku powództwa rodziców oraz bezpośrednio poszkodowanej córki zasądzone zostało łącznie jeden $1 \mathrm{mln} 300$ tys. zł z odsetkami tytułem zadośćuczynienia - z powodów takich jak naruszenie dóbr osobistych i praw pacjenta po stronie matki, naruszenie dóbr osobistych po stronie ojca oraz krzywdę doznaną w związku z uszkodzeniem ciała i rozstrojem zdrowia i naruszeniem dóbr osobistych i praw pacjenta po stronie poszkodowanej. Na rzecz tej ostatniej zostało również zasądzone ponad 60 tys. zł wraz z odsetkami tytułem odszkodowania, ponad 5700 zł wraz z odsetkami tytułem skapitalizowanej renty oraz miesięczna renta w kwocie ponad 2800 zł. Odszkodowanie i zadośćuczynienie zostało zasądzone in solidum od odpowiedzialnego deliktowo szpitala oraz zakładu ubezpieczeń, który zawarł z nim umowę ubezpieczenia OC.

Na skutek błędów popełnionych podczas długotrwałego i skomplikowanego porodu (m.in. braku podjęcia decyzji o cesarskim cięciu] na świat przyszła bezpośrednio poszkodowana - w stanie ciężkiej zamartwicy, bez własnego oddechu, oceniona na 1 punkt w skali Apgar. Od razu po urodzeniu dziecko zostało poddane reanimacji, a następnie umieszczone w inkubatorze. W trakcie dalszej hospitalizacji stwierdzono u niego ponadto krwiaki w okolicach głowy oraz żółtaczkę, a następnie postawiono podejrzenie mózgowego porażenia dziecięcego oraz wydano w tej sprawie orzeczenie o niepełnosprawności od urodzenia. Po wypisaniu ze szpitala dziecko rozpoczęło proces leczenia i rehabilitację. Dziewczynka wymaga stałej opieki ze względu na ograniczoną możliwość samodzielnej egzystencji, rehabilitacji, szczególnej edukacji oraz zaopatrzenia w specjalistyczny sprzęt medyczny i ortopedyczny. Rokowania co do dalszego rozwoju dziecka oznaczone zostały jako niepomyślne. Z racji zmiany trybu życia oraz ponadprzeciętnego zaangażowania w opiekę nad niepełnosprawnym dzieckiem w małżeństwie powodów zaczęło dochodzić do konfliktów i nieporozumień.

Sad wskazał, że zadośćuczynienie za doznaną krzywdę w postaci cierpień fizycznych i psychicznych musi przedstawiać wartość ekonomicznie zauważalną oraz odczuwalną, a także przynosić poszkodowanemu satysfakcję, ale może spełniać również funkcję represyjną w stosunku do osoby odpowiedzialnej za wyrządzenie krzywdy. Co do konsekwencji poniesionych przez bezpośrednio poszkodowane dziecko rozstrzygnięcie nie pozostawia watpliwości, kontrowersyjne mogłoby natomiast wydawać się - podobnie jak w wyżej opisanych przypadkach - zasądzenie zadośćuczynienia za naruszenie dóbr osobistych wobec rodziców małoletniej. Dobro osobiste, które uległo tutaj naruszeniu, zostało doprecyzowane jako prawo do niezakłóconego życia rodzinnego i prawo do rozwoju osobistego. Uzasadnione zostało to tym, że pokrzywdzeni małżonkowie, w związku z niepełnosprawnością córki, zmuszeni są do rezygnacji z wielu marzeń, osobistych planów oraz do końca życia będa pozbawieni możliwości nawiązania pełnej relacji z córką. Sąd nie odniósł się tutaj, tak jak wyżej wymienione sądy, do kontrowersji wynikających z osobistego charakteru naruszonego dobra.

W powyższych orzeczeniach zauważalna jest spójna tendencja sądów do rozszerzania katalogu dóbr osobistych i zaliczania do tej kategorii prawa do utrzymywania więzi rodzinnych oraz prawa do niezakłóconego życia rodzinnego. W treści uzasadnień można zauważyć również konkretyzację

5. Wyrok Sądu Okręgowego w Warszawie z dnia 4 maja 2017 r., sygn. akt I C 29/15, LEX nr 2488388. 
pojęcia krzywdy w odniesieniu do powyższych stanów faktycznych. Istnieja jednak wypowiedzi doktryny, które wskazuja, że tego rodzaju wyszczególnienie jest niepotrzebne, gdyż samo pojęcie krzywdy jest wystarczające do zasądzenia zadośćuczynienia. ${ }^{6}$

Cel omawianych rozstrzygnięć wydaje się oczywiście słuszny, gdyż potrzeba kompensowania utrudnionej sytuacji życiowej i krzywd emocjonalnych osób najbliższych jest niewatpliwa. Pozostaje jednak pytanie, czy konstrukcja prawa do utrzymywania więzi rodzinnych wpisuje się w katalog dóbr osobistych. W kontekście tej podstawy prawnej wątpliwości budzi również odpowiedzialność zakładów ubezpieczeń.

\section{Orzecznictwo sądów powszechnych oddalające powództwa o zasądzenie zadośćuczynienia pieniężnego na rzecz osób najbliższych wobec bezpośrednio poszkodowanych}

Jak wskazano na wstępie, orzecznictwo sądów powszechnych nie było do tej pory jednolite, a w praktyce sądy orzekały w sposób zupełnie przeciwny do zaprezentowanego w powyżej przywołanym orzecznictwie.

Przykładem może być tutaj wyrok Sądu Okręgowego w Nowym Sączu? W sprawie tej powodowie dochodzili zadośćuczynienia pieniężnego, a powództwo zostało oddalone w całości. W przedmiotowym stanie faktycznym małoletni syn powodów uległ wypadkowi komunikacyjnemu. W wyniku wypadku doznał obrażeń ciała w postaci krwiaka nad - oraz podtwardówkowego okolicy czołowej lewej, krwiaka nadtwardówkowego okolicy ciemieniowej lewej, tetraparezy spastycznej oraz wodogłowia pourazowego. Powodowie w pozwie wskazali, że ich syn w wyniku wypadku stał się osoba głęboko niepełnosprawną, niezdolną do samodzielnego funkcjonowania. Dodatkowo, powodowie zostali pozbawieni możliwości nawiązania kontaktu słownego z synem, wskutek czego utracili wszelką możliwość wychowywania go. Powodowie stracili szansę nawiązania z synem normalnych, typowych relacji, realizowania się w roli rodziców, a ponadto zmuszeni byli do stałej, nieprzerwanej opieki nad synem. Wskazali także, że poszkodowany syn został przez powódkę urodzony w jej 39. roku życia oraz, że była to trzecia ciąża powódki po dwóch poprzednich poronieniach. Powodowie uzasadnili roszczenie podniesione w powództwie naruszeniem ich dobra osobistego w postaci prawa do życia w pełnej rodzinie oraz realizowania się w roli rodziców.

Ubezpieczyciel wniósł o oddalenie powództwa w całości. Oddalając powództwo, sąd zważył, że w wyniku wypadku komunikacyjnego powodowie nie utracili dziecka. Co prawda syn powodów obniósł znaczne obrażenia i jest całkowicie sparaliżowany, lecz nie poniósł on w wyniku obrażeń śmierci. Sąd wskazał także, że powodowie nadal opiekują się synem, a więź emocjonalna nadal istnieje w relacji rodzice-dziecko. Wobec ustalonego stanu faktycznego sąd uznał, że brak podstaw, aby uznać, iż doszło do zerwania czy nawet naruszenia więzi rodzinnej. Sạd wskazał także,

6. Krytycznie na temat poglądów wyrażanych w judykaturze, według których ochronie podlega tylko taka więź, której zerwanie powoduje ból, cierpienie i rodzi poczucie krzywdy - M. Kaliński, Ograniczenie indemnizacji do podmiotów bezpośrednio poszkodowanych w zwiqzku z nowelizacja art. 446 Kodeksu cywilnego, „Przegląd Sądowy" 2014, nr 3, s. 20.

7. Wyrok Sądu Okręgowego w Nowym Sączu z dnia 24 maja 2016 r., sygn. akt I C 956/15, niepubl. 
że obowiązujący stan prawny nie przewiduje możliwości zasądzenia osobie pośrednio poszkodowanej zadośćuczynienia.

Podobnie orzekł Sąd Apelacyjny w Łodzi ${ }^{8}$, oddalając w całości powództwo. W sprawie tej powód dochodził zadośćuczynienia w kwocie 100 tys. zł, a stan faktyczny byłnastępujący: małoletni syn powoda uległ wypadkowi komunikacyjnemu. W wyniku wypadku doznał on ciężkiego urazu ciała - urazu czaszkowo-mózgowego, wieloodłamowego złamania pokrywy czaszki, niedowładu połowicznego lewostronnego oraz w konsekwencji również zaburzeń psychoruchowych. Z dokumentacji medycznej wynikało, że rokowania poprawy stanu zdrowia były niepomyślne, zaś obrażenia mózgu miały charakter trwały. Roszczenie pozwu zostało wywiedzione z naruszenia dóbr osobistych - prawa do nawiązania normalnych więzi i relacji z synem oraz prawa do niezakłóconego życia rodzinnego. Powód wskazał, że nie może korzystać z tych praw ze względu na ciężki uraz syna i z wynikłej z tego konieczności obcowania z niepełnosprawnym fizycznie oraz psychicznie dzieckiem. Powód podkreślał także brak możliwości poprawy stanu zdrowia syna. Z kolei pozwana spółka ubezpieczeniowa wskazała na brak odpowiedzialności po swej stronie, wynikający z ograniczonego zakresu akcesoryjności ubezpieczyciela, jak również z braku związku przyczynowo-skutkowego między wypadkiem komunikacyjnym a naruszeniem prawa do nawiązania normalnych więzi oraz relacji z synem oraz prawa do niezakłóconego życia rodzinnego. Pozwana wskazała także na brak dobra osobistego mogạcego być przedmiotem ochrony.

Oddalając powództwo, sąd zważył, że uznaną za poszkodowaną może być wyłącznie osoba, która została bezpośrednio dotknięta bezprawnym działaniem, i tylko ona może dochodzić roszczeń z tego tytułu. Sąd wskazał, że brak normy generalnej, która chroniłaby interes osoby pośrednio poszkodowanej. Nadto, sąd zauważył, że orzecznictwo, które kwalifikuje więź rodzinna jako dobro osobiste, musi uwzględniać, czy w realiach konkretnego stanu faktycznego mamy do czynienia z dobrem osobistym, czy tylko z dobrem prawnie chronionym. W przedmiotowej sprawie czyn nie spowodował śmierci bezpośrednio poszkodowanego, nie da się stwierdzić utraty więzi. W wyroku sąd wskazał, że uczucia wobec członka rodziny, którego prawa zostały naruszone, a skutkiem tego naruszenia jest kalectwo, nie są odrębnym dobrem osobistym, co oznacza, że w ocenie sądu art. 448 k.c. w zw. z art. 24 k.c. nie może być wykładany w ten sposób, aby uzasadniać roszczenia osób bliskich w związku z niepełnosprawnością fizyczną lub intelektualną osób, które zostały bezpośrednio poszkodowane. Nadto, sąd stwierdził, że umowa ubezpieczenia odpowiedzialności cywilnej posiadacza pojazdu mechanicznego, zgodnie z art. 34 ustawy z dnia 22 maja 2003 roku o ubezpieczeniach obowiązkowych, Ubezpieczeniowym Funduszu Gwarancyjnym i Polskim Biurze Ubezpieczycieli Komunikacyjnych ${ }^{9}$, nie obejmuje odpowiedzialności ubezpieczyciela z tytułu naruszenia dóbr osobistych.

Również Są Okręgowy w Piotrkowie Trybunalskim ${ }^{10}$ oddalił powództwo o zasądzenie zadośćuczynienia w kwocie 80 tys. zł. Sprawa ta dotyczyła wypadku komunikacyjnego brata powódki, którego następstwem były obrażenia ciała - przewlekły stan wegetatywny, niedowład czterokończynowy, pourazowa martwica głowy kości udowej lewej, pourazowa ropowica stawu

8. Wyrok Sadu Apelacyjnego w Łodzi z dnia 14 grudnia 2016 r., sygn. akt I ACa 687/16, niepubl.

9. Ustawa z dnia 22 maja 2003 r. o ubezpieczeniach obowiązkowych, Ubezpieczeniowym Funduszu Gwarancyjnym i Polskim Biurze Ubezpieczycieli Komunikacyjnych (t.j. Dz. U. 2003 nr 124, poz. 1152).

10. Wyrok Sądu Okręgowego w Piotrkowie Trybunalskim z dnia 22 grudnia 2017 r., sygn. akt. I C 1484/16, LEX nr 2446626. 
biodrowego lewego, pourazowa deformacja stawu skokowego prawego. Poszkodowany został zaliczony do znacznego stopnia niepełnosprawności na stałe. Jest niezdolny do samodzielnej egzystencji i wymaga stałej opieki innej osoby.

W pozwie powódka wskazała, że w wyniku wypadku komunikacyjnego doszło do naruszenia jej dobra osobistego w postaci prawa do niezakłóconego życia rodzinnego. Powódka podniosła także, że przed wypadkiem ją i brata łączyła bardzo silna więź, wynikająca z tego, że poszkodowany i powódka to rodzeństwo bliźniacze. Po wypadku więź ta przestała istnieć, natomiast opieka nad bratem jest wyczerpująca - zarówno fizycznie, jak i psychicznie.

Pozwany ubezpieczyciel wniósł o oddalenie powództwa. Wskazał, że na skutek zdarzenia nie doszło do zerwania więzi rodzinnej łączącej powódkę z jej bratem, powódka nadal może się z nim kontaktować, a nawet nim się opiekuje, natomiast wypłacone bratu powódki stała renta i odszkodowanie w łącznej kwocie 700000 zł, umożliwia taką organizację opieki nad nim, żeby powódka nie musiała rezygnować z życia prowadzonego przed wypadkiem brata.

W wyroku sad wskazał, że w aktualnym stanie prawnym brak podstawy do dochodzenia roszczenia o zadośćuczynienie pieniężne z tytułu cierpień psychicznych wywołanych uszkodzeniem ciała lub rozstrojem zdrowia osoby najbliższej. Zdaniem sądu nie dochodzi wówczas do nieodwracalnego zerwania więzi rodzinnej z tą osobą, a jedynie zmiany jej funkcjonowania. Zasady doświadczenia życiowego, potwierdzone realiami sprawy, wskazuja przy tym, że kontakty rodzinne mogą być nawet bliższe i pełniejsze. Możliwość cieszenia się niezakłóconym życiem rodzinnym jest pożądanym celem, ale nie może być ujmowana jako dobro osobiste. Sam stan zadowolenia z życia rodzinnego nie jest prawnie gwarantowany. Relacje rodzinne istnieją i funkcjonują w rożnych uwarunkowaniach, zwykle odbiegających od stanu idealnego, spełniającego wymagania i oczekiwania wszystkich członków rodziny.

Wyrok oddalający powództwo o zadośćuczynienie wydał także Sąd Okręgowy w Szczecinie ${ }^{11}$. Sprawa dotyczyła wypadku komunikacyjnego, w którym córka powodów doznała rozległych obrażeń, urazu czaszkowo-mózgowego. Poszkodowana pozostawała w stanie głębokiej nieprzytomności, z niedowładem spastycznym czterokończynowym w wyniku uszkodzenia rdzenia kręgowego. Powodowie wskazali w pozwie, że utracili faktyczny kontakt z córką, zaś ich życie uległo znacznemu pogorszeniu. Z tego powodowie wywiedli wniosek, że doszło do naruszenia dobra osobistego w postaci prawa do niezakłóconego życia prywatnego i rodzinnego.

Towarzystwo ubezpieczeniowe nie uznało powództwa, podnoszac, że brak dobra osobistego podlegającego ochronie, a zakres akcesoryjnej odpowiedzialności towarzystwa ubezpieczeniowego jest ograniczony. Spółka wskazała także na brak związku przyczynowo-skutkowego pomiędzy zdarzeniem a sytuacją powodów, a w konsekwencji - na pośredni status poszkodowanych powodów.

Sąd w wyroku zważył, że nie istnieje przepis prawa, który dawałaby podstawę do uwzględnienia roszczeń powodów. Sąd wskazał, że co prawda życie rodziców uległo pogorszeniu, lecz nie została zerwana więź z dzieckiem. Więź ta stała się odmienna, ale nie oznacza to, że gorsza. Odmienność ta polega na konieczności dostosowania oczekiwań do stanu zdrowia poszkodowanego dziecka. Sad podkreślił także, że stan zadowolenia z życia rodzinnego nie jest w żaden sposób zagwarantowany. Wyobrażenia członków rodziny w przedmiocie optymalnej wizji rodziny nie zmieniaja w sposób prawnie doniosły więzi rodzinnej. Ponadto sąd zważył, iż ocenę, jaki stan

11. Wyrok Sądu Okręgowego w Szczecinie z dnia 1 lutego 2018 r., sygn. akt. I C 1018/17, niepubl. 
zdrowia poszkodowanego uzasadnia przyjęcie, że doszło do uszczerbku dla dobra osobistego, cechowałaby uznaniowość, a nawet dowolność.

Orzecznictwo sądów powszechnych w sprawach, w których sady oddalały powództwo, cechuje pewna spójność w zakresie uzasadnienia. Naczelnym argumentem używanym przez sạdy powszechne jest uznanie, że prawo do niezakłóconego życia rodzinnego oraz prawo do utrzymania lub nawiązania relacji z członkiem rodziny nie jest dobrem osobistym chronionym na gruncie art. 448 k.c. Nadto sądy uznają, że osoba najbliższa, która dochodzi wypłaty zadośćuczynienia pieniężnego, nie jest osobą bezpośrednio poszkodowana. Sądy wskazują także, że wyłącznie przypadki całkowitego zerwania więzi rodzinnych, które powoduje śmierć osoby bezpośrednio poszkodowanej, są objęte ochrona gwarantowana przez kodeks cywilny.

Argument sądów, który jest istotny z punktu widzenia towarzystw ubezpieczeniowych, polega na uznaniu, że odpowiedzialność akcesoryjna ubezpieczycieli wynika nie tyle z zakresu odpowiedzialności ubezpieczonego, ile z treści art. 34 ustawy z dnia 22 maja 2003 roku o ubezpieczeniach obowiązkowych, Ubezpieczeniowym Funduszu Gwarancyjnym i Polskim Biurze Ubezpieczycieli Komunikacyjnych. Sądy wskazywały zaś, że przepis ten nie obejmuje odpowiedzialności ubezpieczyciela z tytułu naruszenia dóbr osobistych.

Zdaniem autorek argument dotyczący charakteru odpowiedzialności towarzystw jest niezwykle istotny. Należy bowiem szczególnie wyraźnie zauważyć, że nie istnieje żadna forma automatyzmu odpowiedzialności ubezpieczyciela. Odpowiedzialność ta, a w konsekwencji - obowiązek określenia wysokości i wypłaty zadośćuczynienia, będzie zależny od ustalenia odpowiedzialności towarzystwa ubezpieczeń.

\section{Uchwały Sądu Najwyższego z dnia 27 marca 2018 roku}

W sprawie zadośćuczynienia pieniężnego dla osób najbliższych osobom poszkodowanym w dniu 27 marca 2018 roku zostały wydane trzy istotne uchwały Sądu Najwyższego - wszystkie w składzie siedmiu sędziów. Uchwały podjęto na wniosek Rzecznika Finansowego z dnia 21 kwietnia 2017 roku (III CZP 36/17) ${ }^{12}$, na skutek przedstawienia przez Sąd Najwyższy w sprawie o sygnaturze akt I CSK 472/16 zagadnienia prawnego do rozstrzygnięcia składowi siedmiu sędziów Sądu Najwyższego (III CZP 60/17) ${ }^{13}$ oraz z wniosku Komisji Nadzoru Finansowego z dnia 5 lipca 2017 roku (III CZP 69/17) ${ }^{14}$.

Wniosek Rzecznika Finansowego obejmował dwa pytania: „Czy w razie poważnego uszkodzenia ciała lub wywołania rozstroju zdrowia osobom najbliższym poszkodowanego może przysługiwać na podstawie art. 448 k.c. roszczenie o zadośćuczynienie pieniężne z tytułu naruszenia ich własnego dobra osobistego?” oraz - w razie pozytywnej odpowiedzi na powyższe pytanie - „Czy w świetle art. 34 ust. 1 ustawy z dnia 22 maja 2003 roku o ubezpieczeniach obowiązkowych,

12. Wniosek Rzecznika Finansowego z dnia 21 kwietnia 2017 r., sygn. RF/108/17/TML, https://rf.gov.pl/pdf/ RF_do_SN_zadosc_stany_wegetatywne1.pdf [dostęp 16 lipca 2018 r.]

13. Postanowienie Sądu Najwyższego z dnia 21 kwietnia 2017 r., sygn. akt I CSK 472/16 , „Monitor Prawniczy” 2018, nr 8, s. 387.

14. Wniosek Komisji Nadzoru Finansowego z dnia 5 lipca 2017 r., sygn. DPP/WOPIII/0260/10/1/2017/BW, „Biuletyn Sądu Najwyższego" 2017, nr 4, s. 4-5. 
Ubezpieczeniowym Funduszu Gwarancyjnym i Polskim Biurze Ubezpieczycieli Komunikacyjnych (Dz. U. 2016, poz. 2060 z późn. zm.) świadczenie ubezpieczyciela w ramach umowy obowiązkowego ubezpieczenia odpowiedzialności cywilnej posiadaczy pojazdów mechanicznych obejmuje zadośćuczynienie pieniężne za krzywdę z tytułu naruszenia dóbr osobistych osób najbliższych poszkodowanego, który doznał poważnego uszkodzenia ciała lub wywołania rozstroju zdrowia?”.

Podobne zakresowo okazało się postanowienie Sạdu Najwyższego z dnia 21 kwietnia 2017 roku w sprawie przedstawienia składowi siedmiu sędziów Sądu Najwyższego do rozstrzygnięcia zagadnienia prawnego (I CSK 472/16). Sąd Najwyższy w postanowieniu zredagował pytanie „Czy roszczenie o zadośćuczynienie na podstawie art. 448 k.c. w związku z art. 24 § 1 k.c. przysługuje osobom bliskim poszkodowanego także wtedy, gdy na skutek czynu niedozwolonego poszkodowany doznał poważnego uszczerbku na zdrowiu?".

Sąd wskazał także, że z art. 446 § 4 k.c. wynika, że ustawodawca udzielił ochrony temu dobru osobistemu, o którym mowa, tylko w razie zerwania więzi przez śmierć. Co prawda życie członków rodziny poszkodowanego, który doznał poważnego uszczerbku na zdrowiu, ulega pogorszeniu, to jednak ich więź z poszkodowanym zostaje zachowana. Członkowie rodziny poszkodowanego nie tracą tym samym dobra osobistego, jakim jest więź rodzinna, staje się ona jedynie więzią niewątpliwie innego rodzaju, wyrażana jest w inny sposób. Nie można jednak twierdzić, że jest to więź gorsza. Jej odmienność polega na konieczności dostosowania oczekiwań do stanu zdrowia poszkodowanego. Jednakże to, że są to oczekiwania inne niż były w odniesieniu, jak w sprawie niniejszej, do dziecka zdrowego, nie powinno podlegać rekompensacie. W postanowieniu Sąd Najwyższy zauważył także, że w obecnym stanie prawnym żaden przepis prawa nie daje podstawy do przyznania członkom rodziny poszkodowanego, który doznał poważnego uszczerbku na zdrowiu, zadośćuczynienia za naruszenie ich więzi rodzinnej w sytuacji, gdy poszkodowany przeżył.

W uzasadnieniu powyżej przywołanego postanowienia Sąu Najwyższego wskazano, że stan zadowolenia z życia rodzinnego nie jest prawnie gwarantowany. Wyobrażenia i uczucia członków rodziny na temat optymalnej czy wolnej od stresu wizji więzi rodzinnych, swoich praw i obowiązków wynikających z tych obowiązków, sposobu sprawowania pieczy na dzieckiem, braku możliwości utrzymywania kontaktów z dzieckiem w ogóle nie zmieniają w sposób prawnie doniosły ukształtowanej ustawowo więzi rodzinnoprawnej.

Ponadto, ocenę, jaki stan zdrowia poszkodowanego już uzasadnia przyjęcie, że dobro osobiste w postaci więzi rodzinnych zostało naruszone, a jaki na przyjęcie takiego stanowiska nie pozwala, cechowałaby uznaniowość, żeby nie powiedzieć - dowolność.

Komisja Nadzoru Finansowego w swoim wniosku zawarła pytanie „Czy w razie poważnego uszkodzenia ciała lub wywołania rozstroju zdrowia osobom najbliższym poszkodowanego może przysługiwać na podstawie art. 448 Kodeksu cywilnego roszczenie o zadośćuczynienie pieniężne z tytułu naruszenia ich własnego dobra osobistego? Względnie, w przypadku przyjęcia przez Sąd Najwyższy, że odpowiedź na powyższe zagadnienie sprowadza się do kwestii stosowania prawa, nie zaś jego wykładni (w szczególności ze względu na potrzebę ustalenia ad causam charakteru uszkodzenia ciała lub rozstroju zdrowia i skutków takiego stanu dla relacji pomiędzy poszkodowanym a jego najbliższymi], zwracam się o rozstrzygnięcie następującej kwestii: Czy zerwanie więzi łączącej osobę poszkodowana, która doznała poważnego uszkodzenia ciała lub rozstroju zdrowia, z jej osobami najbliższymi, polegające na braku możliwości realizowania kontaktów pomiędzy poszkodowanym a osobami najbliższymi z powodu pozostawania przez poszkodowanego w stanie wyłączającym lub w bardzo znaczącym stopniu ograniczającym samodzielną egzystencję (tzw. 
stan wegetatywny], może stanowić po stronie osób najbliższych poszkodowanego naruszenie ich dóbr osobistych, w tym mogące podlegać kompensacie w postaci zadośćuczynienia na podstawie art. 448 Kodeksu cywilnego?".

Każde z powyższych pytań skupia się na podobnych zagadnieniach. Wskazać można jednak na kwestie, które w sposób klarowny wypływają z uzasadnień wniosków i postanowienia, na które podmioty inicjujące działanie Sądu Najwyższego kładły szczególny nacisk. We wniosku Rzecznika Finansowego wskazano na rozstrój zdrowia oraz poważne uszkodzenie ciała. Rzecznik uwypuklił także charakter i zakres akcesoryjności odpowiedzialności towarzystw ubezpieczeniowych. Sąd Najwyższy w swoim postanowieniu opierał się na zjawisku poważnego uszczerbku na zdrowiu. Komisja Nadzoru Finansowego w swym wniosku wskazała na poważne uszkodzenie ciała lub wywołanie rozstroju zdrowia, które to zjawiska rozumie jako polegajace na niemożności realizowania kontaktów z poszkodowanym przez osoby mu najbliższe ze względu na pozostawanie poszkodowanego w stanie, który wyłącza lub znacznie ogranicza samodzielną egzystencję (tzw. stan wegetatywny).

W dniu 27 marca 2018 roku Sąd Najwyższy podjał uchwały w każdej z trzech wyżej wymienionych spraw w składzie siedmiu sędziów. Uchwały zostały podjęte przez Sąd Najwyższy w brzmieniu „Sąd może przyznać zadośćuczynienie za krzywdę osobom najbliższym poszkodowanego, który na skutek czynu niedozwolonego doznał ciężkiego i trwałego uszczerbku na zdrowiu". W sprawie o sygnaturze akt III CZP 36/17 w pozostałym zakresie Sąd Najwyższy odmówił podjęcia uchwały.

Na dzień sporządzania niniejszego opracowania, Sąd Najwyższy sporządził uzasadnienie wyłącznie do jednej z uchwał przywołanych powyżej, a mianowicie do uchwały III CZP 60/17. Autorki nie sądza jednak, aby pozostałe uzasadnienia uchwał odbiegały w sposób zasadniczy od treści już sporządzonego. Z pewnością jednak będą one rozszerzane do udzielenia odpowiedzi na zagadnienia podnoszone we wnioskach.

Sad Najwyższy słusznie zauważył, że nie został przez ustawodawcę ustalony zamknięty katalog dóbr osobistych. Dlatego też do judykatury należy sprecyzowanie zakresu tego pojęcia. W tym procesie jednak sądy nie tworzą nowych dóbr osobistych, lecz na podstawie elastycznej wykładni przepisów rozpoznajaje, stwierdzają, że w danym czasie istniały w porządku prawnym.

W uzasadnieniu Sąd Najwyższy wskazał, że w jego orzecznictwie konsekwentnie przyjmuje się, że istnieje i podlega ochronie dobro osobiste, którego istotą są więzi łączące osoby bliskie i które najczęściej jest opisywane jako: prawo do życia rodzinnego obejmujące różnego rodzaju więzi ${ }^{15}$, więź emocjonalna łącząca osoby bliskie ${ }^{16}$, więzi rodzinne ${ }^{17}$, więzi rodzinne i szczególna więź emocjonalna między członkami rodziny ${ }^{18}$, więź rodzinna, której zerwanie powoduje ból, cierpienie i rodzi poczucie krzywdy ${ }^{19}$, prawo do życia w rodzinie i utrzymanie tego rodzaju więzi ${ }^{20}$, szczególna emocjonalna więź rodzinna między osobami najbliższymi ${ }^{21}$, relacja z najbliższym członkiem

15. Wyrok Sądu Najwyższego z dnia 14 stycznia 2010 r., IV CSK 307/09, OSNC-ZD 2010, nr C, poz. 91.

16. Wyroki Sądu Najwyższego z dnia 10 listopada 2010 r., II CSK 248/10, OSNC-ZD 2011, nr B, poz. 44 i z dnia 25 maja 2011 r., II CSK 537/10, niepubl.

17. Wyrok Sądu Najwyższego z dnia 11 maja 2011 r., I CSK 621/10, niepubl.

18. Uchwała Sądu Najwyższego z dnia 22 października 2010 r., III CZP 76/10, OSNC-ZD 2011, nr B, poz. 42.

19. Uchwała Sądu Najwyższego z dnia 13 lipca 2011 r., III CZP 32/11, OSNC 2012, nr 1, poz. 10.

20. Wyrok Sądu Najwyższego z dnia 15 marca 2012 r., I CSK 314/11, niepubl.

21. Uchwała Sądu Najwyższego z dnia 7 listopada 2012 r., III CZP 67/12, OSNC 2013, nr 4, poz. 45. 
rodziny ${ }^{22}$, szczególna emocjonalna więź rodzinna ${ }^{23}$ albo silna więź emocjonalna, szczególnie bliska w relacjach rodzinnych ${ }^{24}$.

Sąd Najwyższy wskazał, że dobru osobistemu w postaci więzi rodzinnych sądy powszechne przyznawały ochronę również przed nowelizacją kodeksu cywilnego wprowadzającego art. $446 \S$ $4^{25}$. Sąd Najwyższy uznał - potwierdzając swój dotychczasowy dorobek orzeczniczy - że szczególna więź emocjonalna pomiędzy osobami najbliższymi, wynikająca z przynależnego każdej z nich indywidualnie poczucia bliskości i przywiązania, nierozerwalnie związana z naturą człowieka i kształtująca jego tożsamość, stanowi wartość podlegającą ochronie prawnej na podstawie przepisów o dobrach osobistych (art. 23, 24 i 448 k.c.).

Sąd Najwyższy podkreślił, że w jego ocenie brak podstaw do rozróżnienia między zerwaniem więzi rodzinnej na skutek śmierci oraz niemożliwością nawiązania lub rozwinięcia tej więzi pomiędzy bliskimi z powodu ciężkiego uszkodzenia ciała jednego z nich. Sąd zwrócił jednak uwagę, że nie ma tu mowy o każdej więzi rodzinnej, a jedynie o takiej o charakterze rzeczywistym, opierającej się na silnych i trwałych więziach emocjonalnych. Więzi te muszą objawiać się na zewnątrz, aby możliwe było zweryfikowanie ich w sposób obiektywny.

Sąd Najwyższy uznał, że osobiste stosunki rodzinne są chronione przepisami prawa rodzinnego. Nie należy mylić tego jednak z brakiem możliwości dochodzenia roszczeń powiązanych z więziami rodzinnymi, z wykorzystaniem pozostałych instytucji prawnych. Zdaniem Sądu Najwyższego, istotną rolę w tym procesie odgrywają sądy powszechne, które przekonują o potrzebie ochrony wartości niemajątkowych i możliwości przyznawania zadośćuczynienia pieniężnego za ich naruszenie. Dotychczas często sprzeciwiano się takiej koncepcji, powołując argument, który jak się wydaje stracił na aktualności, że krzywdy takiej nie można mierzyć wartościami materialnymi. Ciężko jednak kategorycznie zgodzić się z takim stwierdzeniem. Chociaż niewątpliwie niełatwym zadaniem jest dokonanie wyceny krzywdy i określenie jej w wielkości materialnej, to zabieg ten nie jest niemożliwy do wykonania. W ocenie autorek każda krzywda boryka się z tym rodzajem problemu - trudnością zmierzenia jej wartości materialnej.

Sạd Najwyższy przyznaje, że krzywda związana ze śmiercią osoby najbliższej i ta związana z jej ciężkim uszczerbkiem na zdrowiu nie sạ identycznie. Niemniej jednak, nie ma podstaw do uznania, że dobro nie ucierpiało ciężko w wyniku takiego zdarzenia, chociaż sposób ucierpienia jest inny. Sąd Najwyższy uznał także, że w razie pozostawania osoby najbliższej w nieodwracalnym stanie śpiączki lub w trwałym stanie wegetatywnym dochodzi do podobnych skutków jak w przypadku śmierci, a sytuacja taka jest porównywalna z zerwaniem więzi z osobą bliską, która straciła życie. W okolicznościach trwałego i nieodwracalnego uszkodzenia mózgu cierpienie osoby bliskiej może być nie mniej dojmujące niż doświadczenie śmierci bliskiego. Twierdzenie, że naruszenie dobra osobistego może polegać tylko na jego definitywnym unicestwieniu z powodu śmierci jednej z osób połączonych więzami bliskości, a nie zrywa się dopóty, dopóki osoba ta żyje, nie uwzględnia

22. Wyrok Sądu Najwyższego z dnia 11 lipca 2012 r., II CSK 677/11, LEX nr 1228438.

23. Uchwała Sądu Najwyższego z dnia 20 grudnia 2012 r., III CZP 93/12, OSNC 2013, nr 7-8, poz. 84.

24. Uchwała Sądu Najwyższego z dnia 12 grudnia 2013 r., III CZP 74/13, OSNC 2014, nr 9, poz. 88 i wyrok z dnia 20 sierpnia 2015 r., II CSK 595/14, LEX nr 1809874.

25. Por. wyroki Sądu Apelacyjnego w Gdańsku z dnia 23 września 2005 r., I ACa 554/05, „Palestra” 2006, nr 9-10, poz. 308 i z dnia 14 grudnia 2007 r., I ACa 1137/07, „Przegląd Orzecznictwa Sądu Apelacyjnego w Gdańsku” 2008, nr 1, s. 55. 
bogactwa i złożoności czynników tworzących tę więź, do której podtrzymania nie wystarczy jedynie zachowanie egzystencji fizycznej. Także w ocenie autorek nie jest możliwe dokonanie jednoznacznej oceny różnicy między utratą kontaktu z osobą najbliższą wskutek śmierci oraz wskutek pozostawania przez tę osobę w stanie wyłączającym kontakt z nią. Można nawet zastanowić się nad bardziej długotrwałą krzywdą w tym drugim przypadku, gdy osoba najbliższa fizycznie jest obecna, lecz członkowie jej rodziny nie mogą mimo tej obecności nawiązać z nią kontaktu.

Problemu nie można też postrzegać w kategoriach istnienia więzi lepszej lub gorszej, nie chodzi bowiem o wartościowanie więzi pomiędzy bliskimi, lecz o istnienie lub nieistnienie wszystkich czynników, które tę więź tworzą. Ogólne stwierdzenie, że nie każda krzywda może i musi być naprawiona, nie utrzymuje się w konfrontacji z okolicznościami, w których nie jest rozważany wypadek losowy lub nieszczęśliwy zbieg okoliczności, lecz sytuacja, gdy szkoda (krzywda) została wyrządzona wskutek bezprawnej ingerencji w sferę chronionego prawnie dobra przez osobę trzecia - sprawcę czynu niedozwolonego, z jego winy. W takich sytuacjach ocena wielkości krzywdy, a w konsekwencji - podjęcie skutecznej próby określenia tej wielkości miarą materialna - powinny zostać dokonane. Zdaniem autorek nie byłoby celowym stwierdzenie, że każda sytuacja zasługuje na takie badanie.

Stwierdzenie istnienia dobra osobistego w postaci szczególnej więzi emocjonalnej między najbliższymi należy odgraniczyć od jego naruszenia w konkretnym wypadku. Co oczywiste, także istnienie naruszenia powinno być oceniane każdorazowo, na podstawie konkretnych cech sprawy, z użyciem obiektywnych kryteriów. Orzeczenia dotyczące możliwości przyznania zadośćuczynienia na podstawie art. 448 k.c. w przypadku śmierci osoby bliskiej oraz dopuszczające możliwość przyznania zadośćuczynienia w razie doznania przez osobę bliską ciężkiego uszkodzenia ciała świadczą o stosowaniu takich właśnie kryteriów i nie dostarczaja powodów do obaw o „automatyzm" przy wyrokowaniu.

W wyrokowaniu, zdaniem Sądu Najwyższego, konieczne jest wyznaczenie rozsądnych granic odpowiedzialności. Po pierwsze, naruszenie dobra osobistego w postaci więzi bliskości następuje tylko w razie istnienia szczególnie silnego stosunku emocjonalnego i psychicznego o charakterze rzeczywistym i trwałym. Nie chodzi więc o abstrakcyjnie ujętą więź emocjonalna, ale o szczególny charakter związku między najbliższymi. Po wtóre, o naruszeniu więzi pomiędzy tymi osobami w sposób uzasadniający roszczenie oparte na art. 448 k.c. można mówić jedynie w okolicznościach wyjątkowych, w których doszło nie do zaburzenia, zakłócenia lub pogorszenia więzi, lecz do faktycznej niemożliwości nawiązania i utrzymywania kontaktu właściwego dla danego rodzaju stosunków - w szczególności więzi łączącej dzieci i rodziców - z powodu ciężkiego i głębokiego stanu upośledzenia funkcji życiowych. Dotyczy to zatem uszczerbków zdrowia najcięższych i nieodwracalnych, a więc takich, w których naruszenie więzi rodzinnej wiąże się z dotkliwą, niekończąca się krzywdą i jest porównywalne z krzywdą związaną z definitywną utratą osoby najbliższej. Ustalenie wskazanych okoliczności, przy zastosowaniu kryteriów obiektywnych, powinno stanowić miarodajna podstawę faktyczną oceny, czy doszło do naruszenia przez sprawcę czynu niedozwolonego dóbr osobistych osoby bliskiej przez uniemożliwienie utrzymywania więzi rodzinnej we właściwych jej przejawach. Ocena wszystkich przesłanek jest dokonywana na podstawie konkretnych okoliczności, które ma obowiązek wykazać dochodzący zadośćuczynienia na podstawie art. 448 k.c.

Sąd Najwyższy wskazał także, że trudności, które mogą się wiązać z ustaleniem i oceną tych przesłanek w sposób zindywidualizowany i zarazem zobiektywizowany, nie uzasadniają obawy 
0 „uznaniowość” lub „dowolność” orzekania. Rolą sądów powszechnych będzie zatem zbadanie i dogłębna ocena zasadności oraz wysokości zadośćuczynienia.

\section{Znaczenie uchwał Sądu Najwyższego dla rynku ubezpieczeniowego}

Wśród praktyków istnieją rozbieżne poglądy na temat zasadności wypłacania zadośćuczynienia za krzywdę spowodowana pozostawaniem przez osobę najbliższą w stanie, który uniemożliwia jej samodzielne funkcjonowanie, jak również na temat wysokości takiej wypłaty. Jak wskazał Sąd Najwyższy, główną rolę w obydwu tych kwestiach odegrać będą musiały sądy powszechne. Do czasu ustanowienia praktyki rynkowej oraz orzeczniczej, powstawać moga liczne i bardzo skomplikowane spory między ubezpieczycielami a osobami najbliższymi osób poszkodowanych, dochodzącymi zadośćuczynienia pieniężnego.

W związku z nieostrymi przesłankami ustalenia istnienia prawa do zadośćuczynienia oraz jego wysokości konieczne będzie przeprowadzenie dokładnej analizy każdego stanu faktycznego sprawy. Przy rozpatrywaniu spraw dotyczących złożonych do ubezpieczycieli wniosków o wypłatę zadośćuczynienia przez osoby najbliższe wobec osób bezpośrednio poszkodowanych należy niewạtpliwie brać pod uwagę szereg okoliczności, które wymagają dogłębnej analizy. Uzasadnienie sporządzone do uchwały III CZP 60/17 daje praktyczna podpowiedź, jakie okoliczności i w jaki sposób należy analizować. Przede wszystkim, istotną okolicznością wymagającą analizy będzie faktyczny układ relacji rodzinnych. Badaniu podlegać powinno to, czy więzi te istnieją i czy są to więzi bliskie.

Kwestią, którą z całą pewnością należy wziąć pod uwagę przy rozpatrywaniu spraw z omawianego zakresu, jest zbadanie, czy stan zdrowia osoby bezpośrednio poszkodowanej jest aktualny w momencie składania wniosku, a także w chwili rozpatrywania zgłoszonego roszczenia. Przy rozpatrywaniu wniosków o wypłatę zadośćuczynienia pieniężnego ubezpieczyciele powinni również przeanalizować stan zdrowia osoby bezpośrednio poszkodowanej pod kątem ewentualnych szans jego poprawy. Analiza ta powinna prowadzić do udzielenia odpowiedzi na pytanie, czy możliwe jest zastosowanie pomocy w zakresie rehabilitacji celem maksymalizacji szans poprawy stanu zdrowia osoby, która została bezpośrednio poszkodowana.

Towarzystwa ubezpieczeniowe mają również przed sobą niełatwe zadanie: dokładne zbadanie treści uzasadnienia wniosku o wypłatę zadośćuczynienia pieniężnego oraz wszelkiej dokumentacji, którą ubezpieczyciel zgromadzi w trakcie rozpatrywania zgłoszonego roszczenia. Ubezpieczyciel powinien sprawdzić, czy w danej sprawie są spełniane podstawowe przesłanki wypłaty zadośćuczynienia osobie najbliższej poszkodowanemu.

Wskazać należy również, że odpowiedzialność towarzystw ubezpieczeniowych, nawet - a może i zwłaszcza - w obliczu uchwał Sądu Najwyższego wydanych w sprawach prowadzonych pod sygnaturami akt III CZP 36/17, III CZP 60/17 oraz III CZP 69/17, nie jest odpowiedzialnościa automatyczną. Oznacza to, że towarzystwa nie maja ani obowiązku, ani podstawy prawnej do uwzględniania każdego z roszczeń i wypłaty zadośćuczynienia w każdej ze zgłaszanych do nich spraw o wypłatę. Należy pamiętać, że odpowiedzialność towarzystwa jest wyłącznie odpowiedzialnościa akcesoryjna, pochodną w stosunku do odpowiedzialności sprawcy i zawiera się w granicach tej odpowiedzialności.

Na koniec należy zaznaczyć, że uchwały Sądu Najwyższego z 27 marca 2018 roku, o których mowa powyżej, stanowią postulaty de lege ferenda, nie są zaś faktycznymi wytycznymi dla sądów 
powszechnych. W tym miejscu istotne wydaje się powołanie na wyrok Sądu Najwyższego z dnia 17 maja 2017 roku w sprawie prowadzonej pod sygnatura V CSK 466/16 ${ }^{26}$. W wyroku tym wskazano, że sąd powszechny, rozpoznając sprawę, nie jest związany uchwałami Sądu Najwyższego, nawet uchwałami o mocy zasady prawnej, jeżeli nie zostały wydane w tej samej sprawie. Nie może być jednak wạtpliwości, że zajęcie odmiennego stanowiska wymaga przedstawienia argumentacji, która mogłaby skłonić Sąd Najwyższy do rozważenia potrzeby przedstawienia określonego zagadnienia składowi pełnej izby.

Uchwały podjęte przez Są Najwyższy daja pewne wskazówki, w jakim kierunku należy badać roszczenia o wypłatę zadośćuczynienia w sprawach osób najbliższych osobom bezpośrednio poszkodowanym. Nie dają one jednak jasnej i zawsze klarownej odpowiedzi, kiedy i w jakiej wysokości należne jest zadośćuczynienie. Rola ustalenia tych kwestii przypadać będzie rynkowi ubezpieczeniowemu oraz sądom powszechnym.

\section{Podsumowanie}

Kwestia zadośćuczynienia pieniężnego dla osób najbliższych osobom bezpośrednio poszkodowanym od lat była rozpatrywana przez sądy powszechne. Ze względu na różnice poglądów pomiędzy poszczególnymi sądami, sprawy te rozpatrywane były w różny sposób, co doprowadziło w konsekwencji do stworzenia niespójnej linii orzeczniczej. Także argumentacja sądów - zarówno tych zasądzających zadośćuczynienia, jak i tych oddalających powództwa o ich zasądzenie była prowadzona z odmiennych perspektyw. Sądy brały pod uwagę całkowicie różne okoliczności i konteksty, a w konsekwencji dochodziły do różnych rozstrzygnięć. Sąd Najwyższy uchwałami wydanymi w dniu 27 marca 2018 roku w sprawach prowadzonych pod sygnatura akt III CZP 36/1?, III CZP 60/17 oraz III CZP 69/17 wskazał, że sąd może przyznać zadośćuczynienie za krzywdę osobom najbliższym poszkodowanego, który na skutek czynu niedozwolonego doznał ciężkiego i trwałego uszczerbku na zdrowiu. Sąd Najwyższy wskazał także generalne wskazówki, którymi sądy powszechne kierować winny się przy wyrokowaniu. Nie wydaje się bowiem celowe, by każdy poważny uszczerbek na zdrowiu był podstawą do uzyskania rekompensaty za naruszenie dobra osobistego w postaci więzi rodzinnej27. Uchwały te są o tyle istotne dla rynku ubezpieczeniowego i judykatury, że wskazują zasady ogólne, ułatwiające ocenę zasadności roszczeń o wypłatę zadośćuczynienia. Niemniej jednak rynek ubezpieczeniowy czeka jeszcze długa droga do utworzenia stabilnych reguł w zakresie rozpatrywania roszczeń o wypłatę zadośćuczynień na rzecz osób najbliższych osobom bezpośrednio poszkodowanym. W niedalekim czasie można się spodziewać rozwoju dorobku judykatury w tym zakresie.

Wspomnieć można również, iż kontrowersje zauważalne w orzecznictwie i doktrynie moga sugerować, że celowe wydaje się uregulowanie statusu osób najbliższych osoby bezpośrednio poszkodowanej niezdolnej do samodzielnej egzystencji w taki sposób, by kompensowanie ich

26. Wyrok Sądu Najwyższego z dnia 17 maja 2017 r., V CSK 466/16, LEX nr 2321903.

27. W doktrynie krytykowana jest przede wszystkim hipotetyczna sytuacja, w której tego rodzaju roszczenia zasądzane byłyby automatycznie. Por. E. Bagińska, Dopuszczalność dochodzenia przez osoby bliskie zadośćuczynienia w zwiqzku z doznaniem poważnej szkody na osobie przez bezpośrednio poszkodowanego, "lustitia” 2016, nr 2(24), s. 78. 
krzywd było możliwe na podstawie jasnych i niebudzących wątpliwości przepisów. Słusznie wskazuje się w piśmiennictwie, że wykorzystywanie instytucji dóbr osobistych budzi wạtpliwości z punktu widzenia teoretycznego i prowadzi być może do jej nadużywania, przede wszystkim w sferze prawa rozwodowego 28 .

Powyższe stwierdzenia należy jednak pozostawić w sferze postulatów de lege ferenda. Pomocnym dla polskich sądów może być również odwołanie się do doświadczeń sądów innych krajów europejskich w przedmiotowych sprawach ${ }^{29}$.

\section{Wykaz źródeł}

Bagińska E., Dopuszczalność dochodzenia przez osoby bliskie zadośćuczynienia w zwiqzku z doznaniem poważnej szkody na osobie przez bezpośrednio poszkodowanego, ,lustitia” $2016 \mathrm{nr}$ $2(24)$.

Janiszewska B., 0 ustalaniu wysokości zadośćuczynienia za krzywdę, „Monitor Prawniczy” 2015, nr 23.

Kaliński M., Ograniczenie indemnizacji do podmiotów bezpośrednio poszkodowanych w zwiqzku z nowelizacja art. 446 Kodeksu Cywilnego, „Przegląd Sądowy” 2014, nr 3.

Michałowska K., Niemajatkowe wartości życia rodzinnego w polskim prawie cywilnym, www.sip. legalis.pl [dostęp: 1.10.2018].

Szymańska vel Szymanek P., Zadośćuczynienie za poważny uszczerbek na zdrowiu najbliższego członka rodziny, „Monitor Prawniczy” 2018, nr 11.

Wałachowska M., Roszczenie o zadośćuczynienie pieniężne za zerwanie więzi rodzinnych w razie doznania przez osobę bliska poważnego uszczerbku na zdrowiu, „Przegląd Sądowy” 2017 nr 9.

Wniosek Rzecznika Finansowego z dnia 21 kwietnia 2017 r., sygn. RF/108/17/TML w: https://rf.gov.

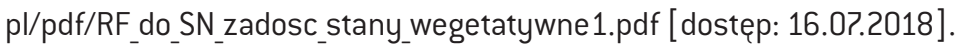

Wniosek Komisji Nadzoru Finansowego z dnia 5 lipca 2017 r., sygn. DPP/WOPIII/0260/10/1/2017/ BW, „Biuletyn Sądu Najwyższego” 2017, nr 4.

28. P. Szymańska vel Szymanek, Zadośćuczynienie za poważny uszczerbek na zdrowiu najbliższego członka rodziny, „Monitor Prawniczy” 2018, nr 11, s. 604.

29. Wskazuje się, że sądy krajów takich jak Francja, Włochy, Anglia, Hiszpania i Portugalia wyznaczyły granice kompensacji w przedmiotowych sprawach, a zasądzanie przez nich roszczeń analogicznych jak omawiane w niniejszym artykule należy uważać za wyjątkowe. Zob. M. Wałachowska, Roszczenie o zadośćuczynienie pieniężne za zerwanie więzi rodzinnych w razie doznania przez osobę bliska poważnego uszczerbku na zdrowiu, „Przegląd Sadowy” 2017, nr 9, s. 23. 


\section{Pecuniary compensation for harm of persons closest to directly injured and the liability of insurance companies - overview of the judicature}

Compensation for harm of persons closest to directly injured is a significant challenge not only for insurance companies but also for the courts. The article provides a development of inconsistent judicature in the present cases and its consequences to insurance market.

In the first part the authors describe judgements granting pecuniary compensation to persons closest to directly injured taking into account extended interpretation of civil law provisions. In the further part the authors present judgements dismissing the claims and referring to traditional understanding of personal rights law. Subsequently the article discusses resolutions of the Supreme Court which provided the attempt of uniforming the interpretation of provisions significant for the present cases. Their importance for the insurance market is also emphasized.

In the conclusions the authors point out that there is a necessity to create firm and coherent rules of granting compensation for above mentioned harm in insurance companies. They also highlight the importance of the Supreme Court's resolutions for establishing consisted policy in the above mentioned cases. Conclusions provide also the necessity to create clear and unambiguous regulations which could be the basis for granting due compensation to the harmed families.

Key words: compensation, closest persons, directly injured, insurance market, personal rights, protection of personal rights.

MGR KATARZYNA CHOJECKA - doktorantka w Katedrze Prawa i Postępowania Administracyjnego Wydziału Prawa i Administracji Uniwersytetu Warszawskiego, e-mail:k.chojecka00@gmail.com

MGR KATARZYNA WIŚNIEWSKA - doktorantka w Katedrze Postępowania Cywilnego Wydziału Prawa i Administracji Uniwersytetu Warszawskiego, radca prawny, e-mail: wisniewska.katarzyna.m@gmail.com 
